\title{
Effect of Pepper Types on Obtaining Spontaneous Doubled Haploid Plants via Anther Culture
}

\author{
Davut Keleş \\ Alata Horticultural Research Institute, 33740 Erdemli, Mersin, Turkey
}

\author{
Hasan Pinar \\ Department of Horticulture, Faculty of Agriculture, Erciyes University, \\ 38039 Kayseri, Turkey
}

Atilla Ata

Alata Horticultural Research Institute, 33740 Erdemli, Mersin, Turkey

\author{
Hatıra Taşkın' ${ }^{1}$ \\ Department of Horticulture, Faculty of Agriculture, Çukurova University, \\ 01330 Adana, Turkey
}

\section{Serhat Yildiz \\ Alata Horticultural Research Institute, 33740 Erdemli, Mersin, Turkey}

\section{Saadet Büyükalaca}

Department of Horticulture, Faculty of Agriculture, Çukurova University, 01330 Adana, Turkey

Additional index words. anther culture, Capsicum annuum, pepper, spontaneous chromosome doubling

\begin{abstract}
The most successful technique used to obtain haploid plant in pepper is anther culture. The chromosome content of haploid plants can be doubled spontaneously or using colchicine. In this study, we compared the rate of spontaneous doubled haploidy of different pepper types. Seven charleston, six bell, eight capia, and seven green pepper genotypes were used as plant material. Murashige and Skoog (MS) nutrient medium with $4 \mathbf{m g} \cdot \mathrm{L}^{-1}$ naphthaleneacetic acid (NAA), $0.5 \mathrm{mg} \cdot \mathrm{L}^{-1}$ 6-benzylaminopurine (BAP), $0.25 \%$ activated charcoal, $30 \mathrm{~g} \cdot \mathrm{L}^{-1}$ sucrose, and $15 \mathrm{mg} \cdot \mathrm{L}^{-1}$ silver nitrate $\left(\mathrm{AgNO}_{3}\right)$ was used. Ploidy levels of plants obtained through anther culture were detected using both flow cytometry and simple sequence repeats (SSR) markers. The results showed that different spontaneous doubled haploidy rates were obtained from different pepper types. The highest rate was observed in bell pepper type with $\mathbf{5 3 . 4 \%}$ (mean of six genotypes) of haploid plants undergoing spontaneous chromosome doubling. This was followed by charleston and capia types with $31.9 \%$ and $30.4 \%$ doubling, respectively. Green pepper type gave the lowest spontaneous doubled haploidy rate with $\mathbf{2 2 . 2 \%}$ doubling. The results obtained from this study will be useful both for future work on haploidy in pepper and for breeding programs.
\end{abstract}

Peppers are a commonly consumed vegetable worldwide and are especially popular in the Mediterranean basin including Turkey. Peppers are grown in almost every region of Turkey and are consumed in various forms (fresh, pepper paste, sauce, pickle, and as spices). There are different consumption methods for different pepper types. For example, bell peppers are used for the preparation

Received for publication 16 July 2015. Accepted for publication 8 Sept. 2015.

We would like to thank the Alata Horticultural Research Institute and the Republic of Turkey Ministry of Food, Agriculture and Livestock for supporting this research. We are also grateful to Anne Frary for critical reading of the manuscript for English.

${ }^{1}$ Corresponding author. E-mail: hatirataskin1@gmail. com. of a Turkish traditional food, "Dolma." Green and charleston pepper types are consumed raw, cooked, and pickled. Capia pepper type can be used smoked and as pepper paste. Pepper, is known to have originated in central and southern America and belongs to the Solanaceae family with Capsicum annuum L. as the most commonly grown species. Peppers have a high nutritional value and are especially rich in vitamin C with $103 \mathrm{mg} / 100 \mathrm{~g}$ (IBPGR, 1983). In addition, peppers are rich in minerals. A $100 \mathrm{~g}$ portion of green fresh pepper contains 29 calories, $1.1 \mathrm{~g}$ protein, $0.2 \mathrm{~g}$ fat, $92.6 \mathrm{~g}$ water, $4.2 \mathrm{~g}$ carbohydrate, and $1.4 \mathrm{~g}$ cellulose. After China and Mexico, Turkey ranks third in pepper production in the world with 2.1 million tons in 2012 (FAOSTAT, 2013). Problems such as low and high temperatures, pests, and diseases have a negative effect on the quality and yield of pepper production. The most significant way to increase yield per unit area is to develop cultivars that are resistant to such problems.

Haploid plant production methods accelerate plant breeding studies and thus, play an important role in developing new cultivars. Obtaining homozygous pure lines using conventional methods takes a long time: $10-12$ years for open-pollinated and 6-7 years for self-pollinated plants. This time can be shortened up to 2 years using tissue culture techniques. Gynogenesis (ovule and ovarium culture), parthenogenesis (pollination with irradiated pollen), and androgenesis (anther and microspore culture) are commonly used to obtain haploid plants via tissue culture. The success of these methods varies according to the species. Positive results in pepper have been achieved with anther culture (Al Remi et al., 2014; Buyukalaca et al., 2004; Comlekcioglu et al., 2001; Ercan et al., 2006; Gémesné Juhász et al., 2001; Niklas-Nowak et al., 2012; Olszewska et al., 2013; Özkum and Tıpırdamaz, 2002; Taşkın et al., 2011). The advantage of this method is that there are thousands of microspores in each anther and numerous haploid plants can be obtained from a single anther. The main principle of anther culture is the prevention of pollen cell development, which normally results in formation of the male gamete. Instead, the immature pollen cells are induced to form embryos similar to somatic cells. Haploid plants have one set of chromosomes and therefore they are not fertile. Haploid plant chromosomes can be doubled spontaneously or using chemicals such as colchicine. Colchicine treatment is expensive and harmful to both human health and the environment. The International Carnivorous Plant Society suggests that toxic colchicine should only be applied by individuals wearing gloves and other personal protective equipments (Cahill, 2015). Plant losses may also be observed during colchicine application.

The disadvantages of colchicine treatment and requirement for an intensive qualified labor force led breeders to use of spontaneous dihaploidization. So far, studies have shown that different pepper types react to anther culture differently. However, no study has been found in the literature on the difference between various pepper types for spontaneous doubled haploid production. These types of studies are available for barley and wheat (Kahrizi and Mohammadi, 2009; Mirzaei et al., 2011a, 2011b). Thus, it is important for breeders to determine the spontaneous doubled haploidy rate for pepper, which is one of the most important vegetables in the world in terms of both cultivation and consumption. In this study, we investigated the rate of spontaneous doubled haploidy for different pepper types.

\section{Materials and Methods}

Plant material. In the current study, seven charleston, six bell, eight capia, and seven green pepper genotypes were used as plant material (Fig. 1). Pepper seeds were planted 

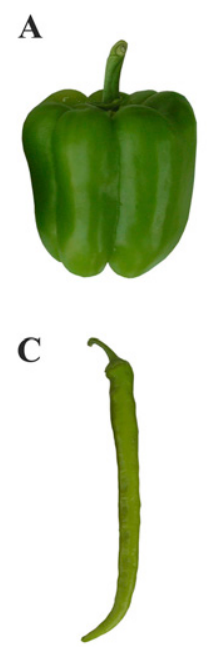

B

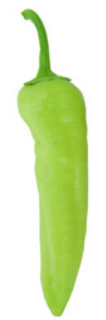

D

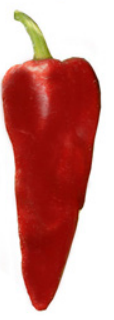

Fig. 1. Representative (A) bell, (B) charleston, (C) green, and (D) capia pepper types.

in plugs containing two volumes peat and one volume perlite. In the study conducted by Buyukalaca et al. (2004), plants grown in the greenhouse were found to have a better response to anther culture than those grown in the open field. Therefore, the plants used in this study were grown in the greenhouse. Normal horticultural cultivation practices such as fertilization, irrigation, and plant protection practices were implemented throughout the growing period.

Anther culture studies. The most proper anther stage for anther culture is the lateuninucleate or early-binucleate phase (the beginning of the first mitotic division). According to Buyukalaca et al. (2004), the length of the corolla should be equal to that of the calyx or slightly longer, and almost half of the anthers have anthocyanin at this phase. Therefore, the flower buds at this step were collected in April and May (determined as the most proper time for the Mediterranean region of Turkey by Ata, 2011; Buyukalaca et al. 2004; Comlekcioglu et al. 2001; Taşkin et al. 2011) and checked by staining with acetocarmine. Flower buds were sterilized with a $15 \%$ sodium hypochlorite solution including 1 to 2 drops of Tween 20 for $15 \mathrm{~min}$, and then rinsed four times in sterile distilled water. After sterilization, the flower buds were dissected, the filaments were removed, and the anthers were placed on nutrient medium in 6-cm-diameter glass petri dishes using sterile forceps and scalpels. Murashige and Skoog (1962) nutrient medium containing $4 \mathrm{mg} \cdot \mathrm{L}^{-1} \mathrm{NAA}, 0.5 \mathrm{mg} \cdot \mathrm{L}^{-1}$ BAP, $0.25 \%$ activated charcoal, $30 \mathrm{~g} \cdot \mathrm{L}^{-1}$ sucrose, and $15 \mathrm{mg} \cdot \mathrm{L}^{-1} \mathrm{AgNO}_{3}$ (Ata, 2011; Buyukalaca et al., 2004; Taşkin et al., 2011) was used as nutrient medium. Cultured anthers were subjected to pretreatment by incubation at $35^{\circ} \mathrm{C}$ in the dark for the first 2 days (Buyukalaca et al., 2004; Dumas de Vaulx et al., 1981, 1982; Irikova et al., 2011; Koleva-Gudeva, 2009; Morrison et al., 1986; Sibi et al., 1980; Taşkin et al., 2011). Then they were transferred to the growth chamber at $25{ }^{\circ} \mathrm{C}$ with 8-h dark and 16-h light photoperiod conditions. Embryos obtained from anthers were transferred to $15-\mathrm{cm}$ glass tubes containing hormone-free MS nutrient medium (Fig. 2).

Flow cytometry studies. The ploidy level of plants was detected using a flow cytometer (Partec, Münster, Germany). Young leaves of plants obtained from anther culture were put into petri dishes containing $400 \mu \mathrm{L}$ extraction buffer (Partec 05-5002 CyStain ${ }^{\circledR}$ ultraviolet Precise P), chopped using a sharp razor blade in petri dishes for 30 to $60 \mathrm{~s}$ and incubated between $30 \mathrm{~s}$ and $5 \mathrm{~min}$. These samples were filtered using a Partec $50 \mu \mathrm{m}$ CellTrics disposable filter. The filtrate was combined with $1.6 \mathrm{~mL}$ staining buffer, incubated for 30 to $60 \mathrm{~s}$ and analyzed in the flow cytometry in the blue fluorescence channel. The ploidy level of each plant was determined according to the peaks (Fig. 3). A diploid commercial cultivar was used as control.

SSR analyses. Embryo type (diploid/doubled haploid) was determined using Hpms 1-117 SSR marker (Fig. 4). More than 20 SSR markers derived from the pepper genome (Sol Genom network) were tested in this study and Hpms 1-117 was selected based on its clear polymorphism. Polymerase chain reactions (PCR) were performed in $15 \mu \mathrm{L}$ volume containing $4.8 \mu \mathrm{L}$ water, $2 \mu \mathrm{L}$ DNA, $1.5 \mu \mathrm{L} 10 \times$ PCR buffer, $0.2 \mu \mathrm{L}$ Taq DNA polymerase $(5 \mathrm{U} / \mu \mathrm{L}), 1 \mu \mathrm{L}$ deoxynucleotide triphosphate $(2.5 \mathrm{~mm}), 1.5 \mu \mathrm{L} \mathrm{MgCl}_{2}(25 \mathrm{~mm})$, $2 \mu \mathrm{L} 10 \mathrm{~mm}$ SSR primer (Fw), and $2 \mu \mathrm{L}$ $10 \mathrm{~mm}$ SSR primer (Rw). Amplifications were conducted using the following program: 1 cycle of $30 \mathrm{~s}$ at $95^{\circ} \mathrm{C}, 35$ cycles of $15 \mathrm{~s}$ at $95^{\circ} \mathrm{C}, 35$ cycles of $30 \mathrm{~s}$ at $55-57^{\circ} \mathrm{C}, 35$ cycles of $30 \mathrm{~s}$ at $72{ }^{\circ} \mathrm{C}, 3 \mathrm{~min}$ at $72{ }^{\circ} \mathrm{C}$, and a $4{ }^{\circ} \mathrm{C}$ soak. Gel electrophoresis in 3\% high-resolution agarose gels run in $0.5 \times$ tri-acetate-EDTA buffer (Scie-Plas Co. Ltd., Southam, Warwickshire, UK) was used to size-fractionate amplicons. To prepare agarose gel, $1 \times$ trisborate-EDTA buffer $(89 \mathrm{~mm}$ Tris, $89 \mathrm{~mm}$ boric acid, and $2 \mathrm{~mm}$ ethylenediaminetetraacetic acid) was used and $25 \mu \mathrm{L}(10 \mathrm{mg} / \mathrm{mL})$ ethidium bromide was added. A 100-base pair DNA ladder was loaded as standard. Then gels were visualized using an ultraviolet transilluminator (Kodak Gel Logic 200, Eastman Kodak Company, Rochester, NY).

Statistical analyses. The experiment was arranged in a "completely randomized design" with three replications and each replication consisted of 100 explants. Data were subjected to one-way analysis of variance. The means and calculated standard deviations are reported. Significant differences between means were evaluated by using Tukey's multiple range test at $P \leq 0.05$ and $P \leq 0.01$. Data giving in percentages were subjected to $x^{\prime}=\arcsin \sqrt{ }(x / 100)$ transformation. All statistical analyses were performed by using SAS v9.00 statistics software.

\section{Results}

In this study, seven charleston, six bell, eight capia, and seven green pepper genotypes were tested to determine the effects of pepper type on obtaining spontaneous doubled haploid plants via anther culture. Seven different genotypes were used to determine the rate of spontaneous doubled haploidy for green peppers. For each genotype, 300 anthers were examined. The highest plant number obtained from anther culture was found to be 6.7 plants per 100 anthers in green type 2 . This genotype was followed by type- 4 , type- 5 , type-6, and type-3 with 5.7, 5.3, 4, and 3.7 plants per 100 anthers, respectively. Rates of spontaneous doubled haploidy were $20 \%$, $25 \%, 9.1 \%, 23.5 \%, 25 \%, 8.3 \%$, and $44.4 \%$ in types 1 to 7 , respectively. The mean spontaneous doubled haploidy rate for green peppers was calculated as $22.2 \%$ (Table 1; Fig. 5).

In charleston pepper type, seven different genotypes were tested. The fewest plants were obtained from charleston type- 4 with 7 plants from 300 anthers; however, three of these plants were doubled haploids. Plant number per 100 anthers varied with values of 6 (type-1), 4.7 (type-2), 7 (type-3), 2.3 (type-4), 6.7 (type-5), 6.7 (type-6), and 10.3 (type-7), depending on genotype. Spontaneous doubled haploidy rates varied between $14.3 \%$ and $44.4 \%$, and the average was found to be $31.9 \%$. The mean plant number was 6.23 per 100 anthers (Table 1; Fig. 6).

Eight pepper genotypes were tested to assess the performance of the capia pepper type. The highest plant numbers were from type- 1 with 14 plants per 100 anthers followed by type-3 (11 plants per 100 anthers), type- 8 ( 8 plants per 100 anthers), type-2 (7.7 plants per 100 anthers), type-5 ( 7.3 plants per 100 anthers), type-6 (6 plants per 100 anthers), type-7 (3.7 plants per 100 anthers), and type 4 (2.7 plants per 100 anthers). The highest spontaneous doubled haploidy rate was observed in type- 4 with $37.5 \%$. The average of the eight genotypes was $30.4 \%$ (Table 1; Fig. 7).

The performance of the bell pepper type was studied with six genotypes and the plant numbers were $12,17,5.7,6.7,20$, and 8.3 plants per 100 anthers in types 1 to 6 , respectively. Spontaneous doubled haploidy rates were above $50 \%$ except for type- 4 with $40 \%$ (Table 1; Fig. 8).

The statistically highest average spontaneous doubled haploidy rate was obtained from bell pepper type with $53.4 \%$ and this was followed by charleston and capia types (charleston: $31.9 \%$, capia: $30.4 \%$ ). The lowest result was observed in green pepper type with $22.2 \%$. One of the importing findings in this study was documentation of the variation in these types. Spontaneous doubled haploidy rates of the tested genotypes of capia $(23.8 \%$, $27.3 \%, 27.3 \%, 30.3 \%, 30.4 \%, 33.3 \%, 33.3 \%$, and $37.5 \%)$ and bell $(52.8 \%, 52.9 \%, 52.9 \%$, $60 \%$, and $61.7 \%$ ) pepper types were found to be more stable than the charleston $(14.3 \%$, $20 \%, 20 \%, 38.7 \%, 42.9 \%, 42.9 \%$, and $44.4 \%$ ) and green $(8.3 \%, 9.1 \%, 20 \%, 23.5 \%, 25 \%$, $25 \%$, and $44.4 \%$ ) pepper types.

The spontaneous doubled haploid plants were tested using flow cytometry and an SSR locus (Fig. 4) to determining whether the plants were doubled haploid or not. These 


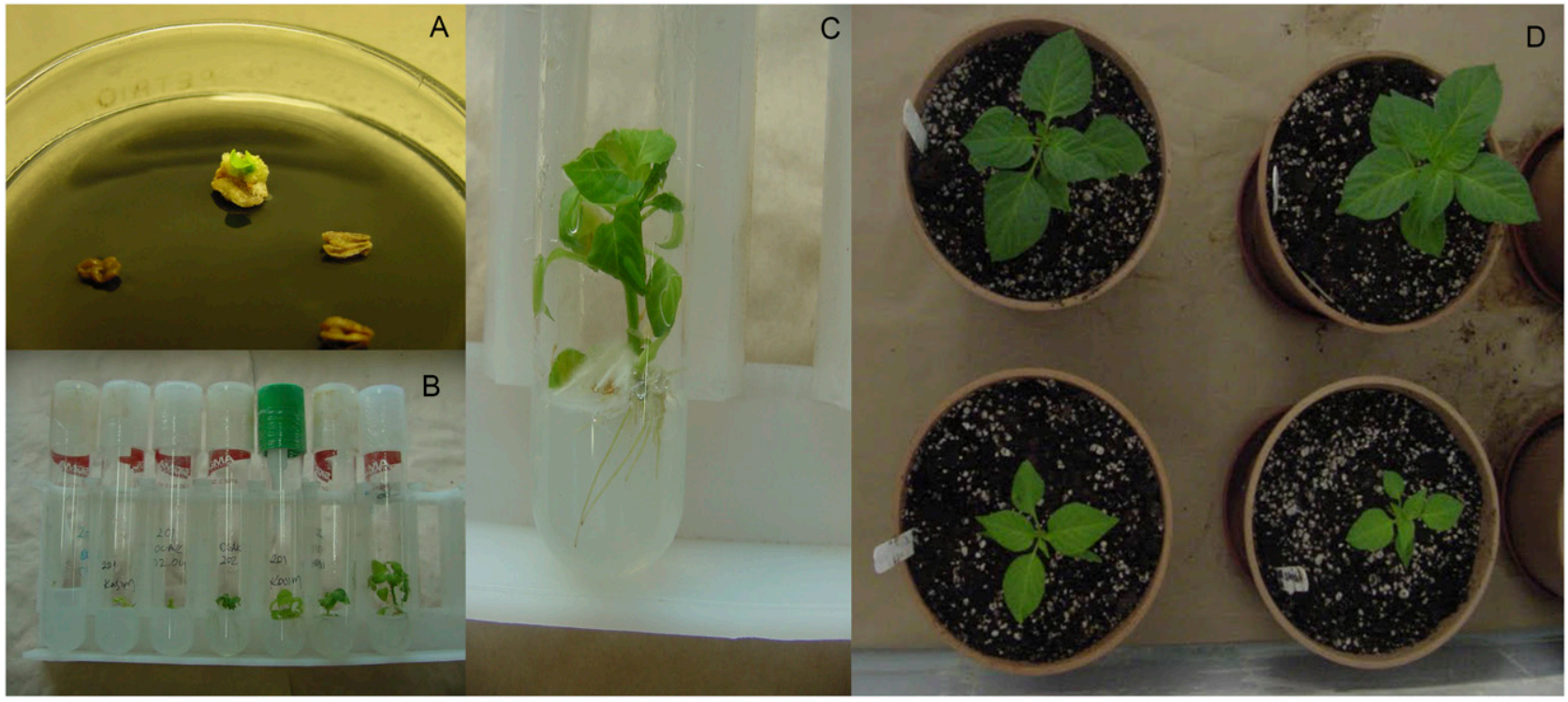

Fig. 2. Development of haploid plants via anther culture. (A) Plant formation in petri dishes, $(\mathbf{B}, \mathbf{C})$ rooting of plants obtained via anther culture in culture tubes, (D) acclimation of plants.

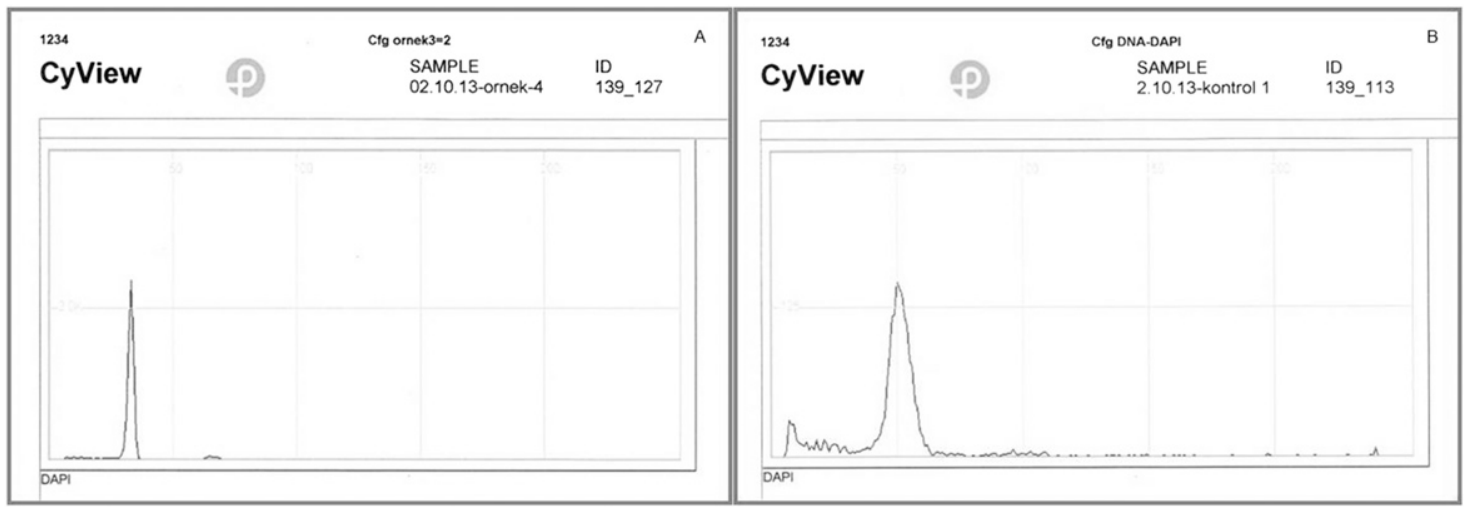

Fig. 3. Flow cytometric analyses of (A) haploid and (B) diploid plants.

tests showed that all doubled haploid plants were homozygous.

\section{Discussion}

Haploid plants are of great importance in plant breeding because they help shorten the breeding process. However, since these plants have half the normal chromosome number, they must be made diploid. Doubling of the chromosomes of haploid plants using chemicals or spontaneously is called dihaploidization. Some chemicals such as colchicine are used for chromosome doubling. These chemicals have certain disadvantages: 1) the chemicals are both expensive and harmful, 2) plant losses may be observed, 3) chemical application requires time and labor, and 4) they are also forbidden for use in the field (for in vivo doubling) in most countries. These disadvantages can be avoided by spontaneous chromosome doubling.

Anther culture is a widely used haploidization technique in pepper. Several studies have been carried out on the development of successful protocols related to pepper anther culture (Abak, 1983; Al Remi et al., 2014; Ata, 2011; Buyukalaca et al., 2004; Comlekcioglu et al., 2001; Gémesné Juhász et al., 2001; George and Narayanaswamy, 1973; Harn et al., 1975; Niklas-Nowak et al., 2012; Novak, 1974; Olszewska et al., 2013; Saccardo and Devreux, 1974; Taşkın et al., 2011; Wang et al., 1973). In these studies, the rate of spontaneous doubled haploidy was determined via ploidy analyses. In a study carried out by Gémesné Juhász et al. (2001), ploidy levels of sweet pepper plants obtained via anther culture were determined through flow cytometry and $68.5 \%$ of the plants were haploid, $29.8 \%$ of the plants were spontaneous doubled haploid, $0.7 \%$ of the plants were tetraploid, and $1 \%$ of the plants were aneuploid. Niklas-Nowak et al. (2012) reported that in pepper, 31 of $63(49 \%)$ plants obtained through anther culture were diploid (two of five plants in $C$. frutescens $\times C$. chinense $\mathrm{F}_{2}$ hybrid lines, six of 13 plants in AT6 DH line, and 23 of 45 plants in ATZ1 $\times$ TGA F $_{2}$ hybrid lines). In an anther culture study carried out by Olszewska et al. (2013), the number of spontaneous doubled haploid plant was reported as

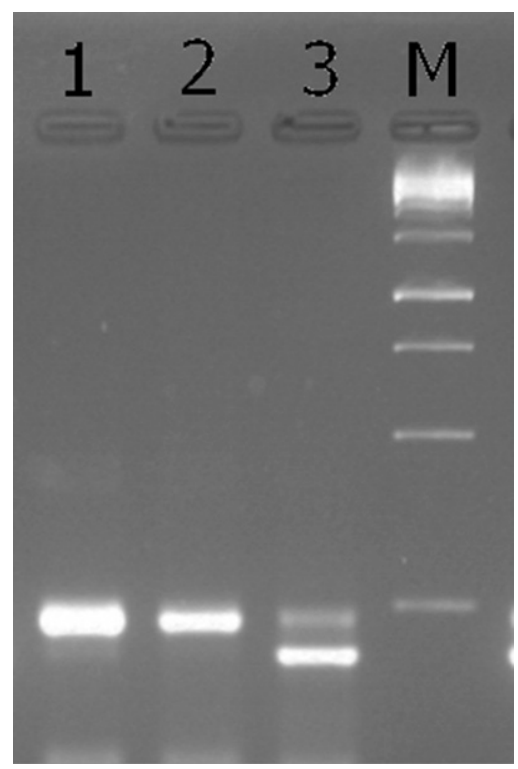

Fig. 4. Gel imaging using Hpms1-117 SSR marker (1) haploid plant, (2) double haploid plant (3) diploid plant, and (M) marker (100 bp ladder). 
Table 1. Plant, haploid, diploid plant number, and spontaneous double haploidy rate in different pepper types.

\begin{tabular}{|c|c|c|c|c|c|}
\hline Species types & Anther no. & P no. & HP no. & DP no. & $\overline{\mathrm{SDH}} \%^{\mathrm{z}}$ \\
\hline Green type-1 & 300 & 5 & 4 & 1 & 20.0 \\
\hline Green type- 2 & 300 & 20 & 13 & 5 & 25.0 \\
\hline Green type-3 & 300 & 11 & 10 & 1 & 9.1 \\
\hline Green type-4 & 300 & 17 & 12 & 4 & 23.5 \\
\hline Green type-5 & 300 & 16 & 12 & 4 & 25.0 \\
\hline Green type- 6 & 300 & 12 & 11 & 1 & 8.3 \\
\hline Green type-7 & 300 & 9 & 5 & 4 & 44.4 \\
\hline Green type & Mean & 12.9 & 9.6 & 2.9 & $22.2 \mathrm{~b}$ \\
\hline Charleston type-1 & 300 & 18 & 10 & 8 & 44.4 \\
\hline Charleston type- 2 & 300 & 14 & 8 & 6 & 42.9 \\
\hline Charleston type-3 & 300 & 21 & 18 & 3 & 14.3 \\
\hline Charleston type-4 & 300 & 7 & 4 & 3 & 42.9 \\
\hline Charleston type- 5 & 300 & 20 & 16 & 4 & 20.0 \\
\hline Charleston type- 6 & 300 & 20 & 19 & 4 & 20.0 \\
\hline Charleston type-7 & 300 & 31 & 19 & 12 & 38.7 \\
\hline Charleston type & Mean & 18.7 & 13.4 & 5.7 & $31.9 \mathrm{~b}$ \\
\hline Capia type-1 & 300 & 42 & 32 & 10 & 23.8 \\
\hline Capia type-2 & 300 & 23 & 16 & 7 & 30.4 \\
\hline Capia type-3 & 300 & 33 & 23 & 10 & 30.3 \\
\hline Capia type- 4 & 300 & 8 & 5 & 3 & 37.5 \\
\hline Capia type-5 & 300 & 22 & 14 & 6 & 27.3 \\
\hline Capia type-6 & 300 & 18 & 12 & 6 & 33.3 \\
\hline Capia type-7 & 300 & 11 & 8 & 3 & 27.3 \\
\hline Capia type- 8 & 300 & 24 & 16 & 8 & 33.3 \\
\hline Capia type & Mean & 22.6 & 15.8 & 6.6 & $30.4 \mathrm{~b}$ \\
\hline Bell type-1 & 300 & 36 & 17 & 19 & 52.8 \\
\hline Bell type-2 & 300 & 51 & 24 & 27 & 52.9 \\
\hline Bell type-3 & 300 & 17 & 8 & 9 & 52.9 \\
\hline Bell type-4 & 300 & 20 & 12 & 8 & 40.0 \\
\hline Bell type-5 & 300 & 60 & 23 & 37 & 61.7 \\
\hline Bell type- 6 & 300 & 25 & 10 & 15 & 60.0 \\
\hline Bell type & Mean & 34.8 & 15.7 & 19.2 & $53.4 \mathrm{a}$ \\
\hline$P>\mathrm{f}$ & 0.0110 & 0.2782 & 0.0001 & 0.0002 & 0.0002 \\
\hline
\end{tabular}

${ }^{\mathrm{z}} \mathrm{SDH}$ was analyzed with arcsin transformed data.

$\mathrm{P}$ no. $=$ Plant number obtained from anther culture; HP no. $=$ haploid plant number; DP no. $=$ diploid plant number; $\mathrm{SDH} \%=$ spontaneous double haploidy rate.

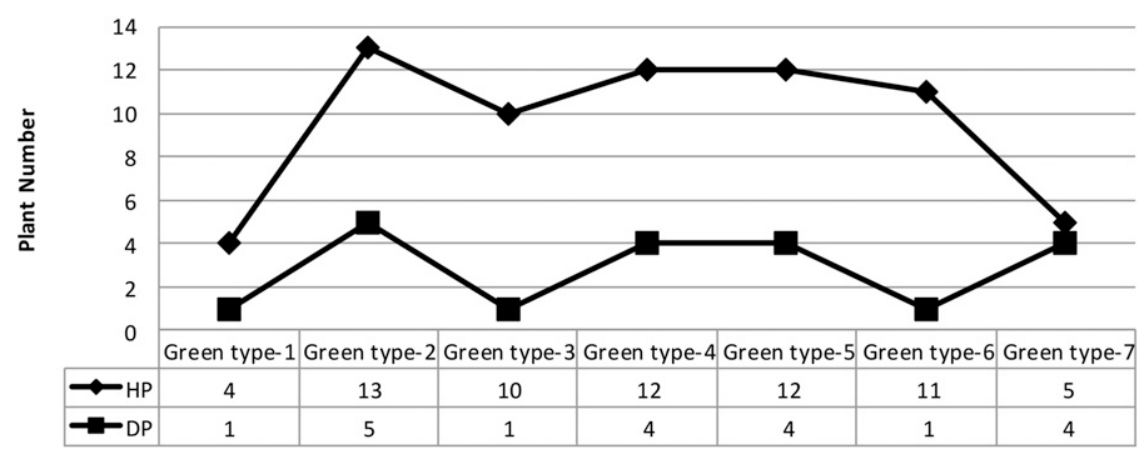

Fig. 5. Haploid and diploid plant number in green pepper types.

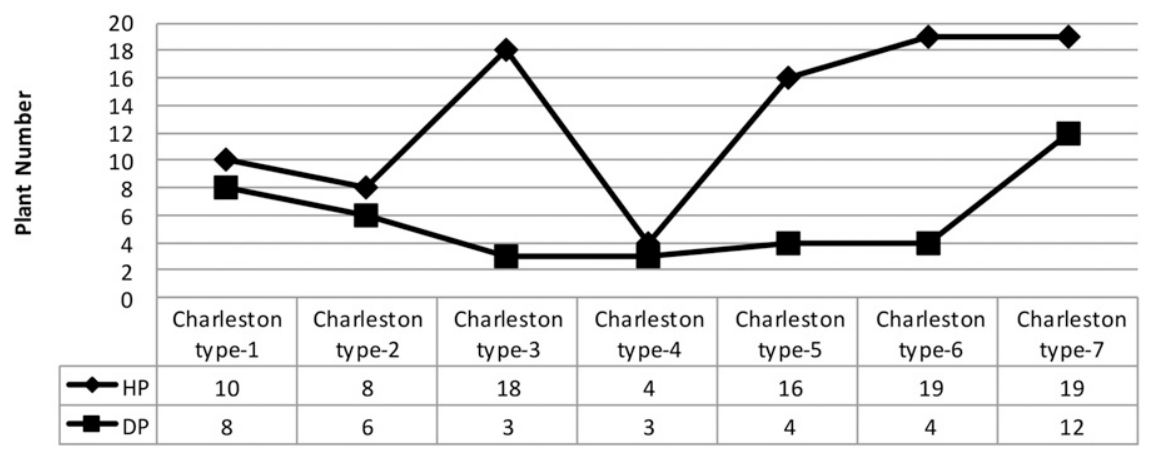

Fig. 6. Haploid and diploid plant number in charleston pepper types. three of five plants in ATZ1 breeding line, one of two plants in PO breeding line, four of six plants in F1 $(\mathrm{ATZ} \times \mathrm{PO})$ line, two of four plants in F1 $($ ATZ1 $\times$ TG), three of five plants in AP40 DH line, six of nine plants in AC7 DH line, one of three plants in $\mathrm{F}_{1}(C$. frutescens $\times$ $C$. chinense) interspecific hybrid line and one of three plants in F1 (C. frutescens $\times C$. baccatum) interspecific hybrid line. In a study on pepper conducted by Al Remi et al. (2014), the rate of spontaneous doubled haploidy was identified as $6 \%$. However, to our knowledge, there is no comparative study indicating the rate of spontaneous doubled haploidy for different types of peppers. The determination of these rates will enable breeders to plan doubled haploid breeding programs depending on pepper type. Spontaneous doubling has been reported in other plant species. In a review study conducted by Kim et al. (2007), spontaneous doubled haploidy in different species such as in rice (Cho and Zapata, 1990), barley (Hoekstra et al., 1993), and wheat (Kim and Baenziger, 2005) were reported. Spontaneous diploidy rate of Brassica rapa ssp. chinensis plants obtained through microspore culture was found to be over $70 \%$ by $\mathrm{Gu}$ et al. (2003). This rate was reported as $7 \%$ for maize anther culture study (Mohammadi et al., 2007). In a study carried out by Vanous (2011) in maize, spontaneous doubled haploidy rates for the male inflorescence varied between $2.8 \%$ and $46 \%$ and were found to be highly genotype specific. El-Hennawy et al. (2011) reported that the spontaneous doubling rate in wheat depended on genotype and was found to be $15 \%$ to $44 \%$ in German cultivars of spring wheat (Stober and Hess, 1997), but $25 \%$ to $68 \%$ in winter wheat cultivars from Central and Eastern Europe (Barnabas, 2003). Kahrizi and Mohammadi (2009) obtained the highest spontaneous haploidy rate $(76 \%)$ for barley from a genotype, which had the lowest embryogenic potential and the lowest rate $(65 \%)$ from a genotype with the highest androgenic capacity. Similar findings were discovered in wheat by Mirzaei et al. (2011a). They found a negative relationship between embryogenesis and spontaneous chromosome doubling in wheat. We did not observe any negative relationship between embryogenesis and spontaneous chromosome doubling in the present work. Mirzaei et al. (2011b) reported that while haploid embryogenesis was affected by barley genotype, spontaneous chromosome doubling was unaffected. However, the researchers emphasized that the means for spontaneous chromosome doubling were high $(63 \%$ and $72 \%$ in the two barley genotypes tested).

In this study, spontaneous doubled haploidy rates in different pepper types were determined. The rates of spontaneous doubling were significantly different for different types of peppers. While the highest rate was $53.4 \%$ in bell pepper and the lowest rate was $22.2 \%$ in green pepper. Not only did bell-type pepper have the highest spontaneous doubled haploidy rate, but also genotypic variation within the type was low. In the light of the results obtained from this study, it can be 


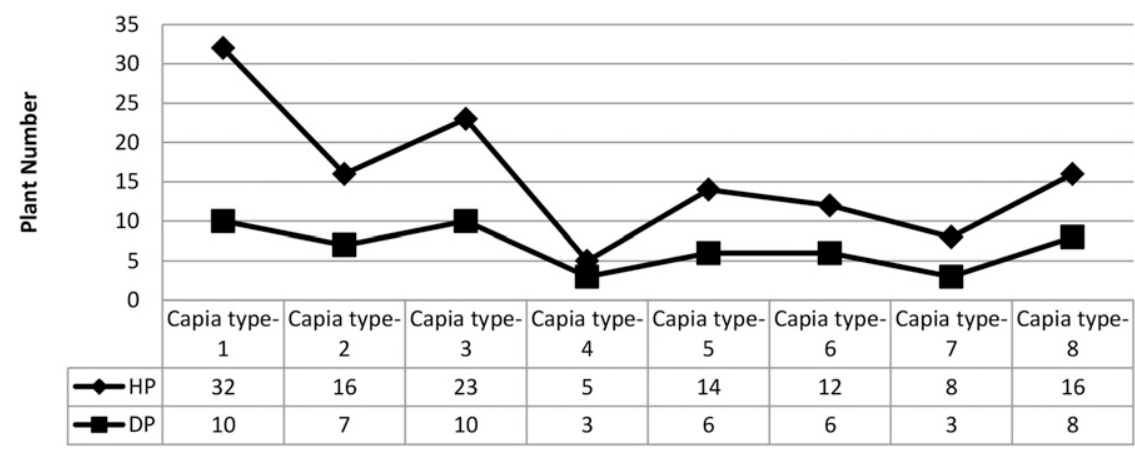

Fig. 7. Haploid and diploid plant number in capia pepper types.

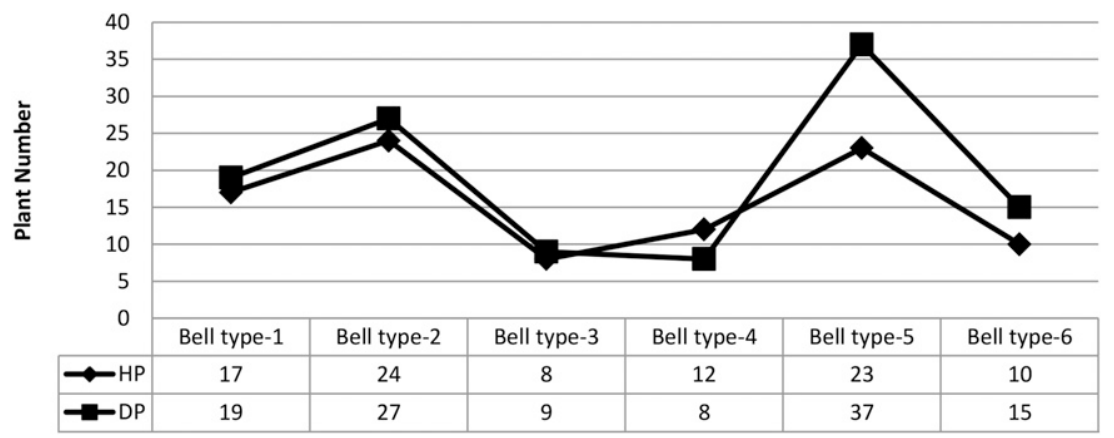

Fig. 8. Haploid and diploid plant number in bell pepper types.

stated that more than $50 \%$ of the plants obtained through anther culture with the bell pepper type can be spontaneously doubled. In this case, in the studies performed with the type of bell pepper before chemical applications for doubling of chromosomes, spontaneous doubled haploid plants can be categorized by determining via flow cytometry. In this way, plant losses resulting from chemical applications can be avoided. Flow cytometry is the most common, reliable, and the fastest technique used to assess numerous cellular characteristics and analyze cells individually (Loureiro et al., 2006; Suda and Travnicek, 2006). The method was initially developed for human cells and then it was adapted for plant cells as a reliable tool for estimation of nuclear DNA content and ploidy level constitutions in plants (Doležel, 1991; Doležel et al., 1994, 1997; Gulsen et al., 2009; Ozkan et al., 2006, 2010; Tuna et al., 2001, 2004, 2006; Tiryaki and Tuna, 2012). In this work, flow cytometry was used to categorize if the plants were haploid or diploid/doubled. Although flow cytometry categorizes the ploidy level of the plants, this method is not able to determine if the diploid plants are doubled haploids or somatic tissue-derived plants. Thus, molecular characterization by a codominant marker system was necessary to determine the homozygosity of the plants. In this study, a codominant SSR marker was used to separate doubled haploid and diploid plants. This test showed that all doubled haploid plants were homozygous. Overall, spontaneous doubled haploidy rates were quite high in all pepper types. Even in green pepper, which had the lowest rate, the spontaneous doubling rate was $22.2 \%$. The results obtained from this study will provide fruitful information for pepper breeding programs that use the dihaploidization technique.

\section{Literature Cited}

Abak, K. 1983. Biberde (Capsicum annuum L.) anter kültürü yoluyla haploid bitki elde etme üzerinde araştırma. Ankara Üniversitesi Ziraat Fakültesi Y1llı̆̆ $133: 155-163$.

Al Remi, F., H. Taşkın, K. Sönmez, S. Büyükalaca, and Ş. Ellialtığlu. 2014. Effect of genotype and nutrient medium on anther culture of pepper (Capsicum annuum L). Turkish J. Agr. Natural Sci. 1:108-116.

Ata, A. 2011. Effect of season on pepper (Capsicum annuиm L.) anther culture and microspore development. Çukurova Univ., Adana, MSc Diss.

Barnabas, B. 2003. Protocol for producing doubled haploid plants from anther culture of wheat (Triticum aestivum L.), p. 65-70. In: M. Maluszynski, K.J. Kasha, B.P. Foster, and I. Szarejko (eds.). Doubled haploid production in crop plants. A Manual. FAO/IAEA Division, Wien.

Buyukalaca, S., N. Comlekcioglu, K. Abak, E. Ekbic, and N. Kilic. 2004. Effect of silver nitrate and donor plant growing conditions on production of pepper (Capsicum annuum $\mathrm{L}$.) haploid embryos via anther culture. Eur. J. Hort. Sci. 69:206-209.

Cahill, T. 2015. Propagation-Colchicine treatment and toxicity. International Carnivorous Plant Society (ICPS). 7 July 2015. <http://www. carnivorousplants.org/howto/Propagation/ Colchicine.php $>$.

Cho, M.S. and F.J. Zapata. 1990. Plant regeneration from isolated microspore of indica rice. Plant Cell Physiol. 31:881-885.

Comlekcioglu, N., S. Buyukalaca, and K. Abak. 2001. Effect of silver nitrate on haploid embryo induction by anther culture in pepper (Capsicum annuum), p. 133-135. In: K. Abak, S. Büyükalaca, and Y. Daşgan (eds.). Proc. of the XI ${ }^{\text {th }}$ EUCARPIA Meeting on Genetics and Breeding of Capsicum \& Eggplant. Eucarpia.

Doležel, J. 1991. Flow cytometric analysis of nuclear DNA content in higher plants. Phytochem. Anal. 2:143-154.

Doležel, J., M. Doleželová, and F.J. Novák. 1994. Flow cytometric estimation of nuclear DNA amount in diploid bananas (Musa acuminata and M. balbisiana). Biol. Plant. 36:351-357.

Doležel, J., M.A. Lysák, I. Van den Houwe, M. Doleželová, and N. Roux. 1997. Use of flow cytometry for rapid ploidy determination in Musa species. Infomusa 6:6-9.

Dumas de Vaulx, R., D. Chambonnet, and E. Pochard. 1981. In vitro anther culture in red pepper (Capsicum annuum L.): Improvement of the rate of plant production in different genotypes by treatments at $35^{\circ} \mathrm{C}$. Agronomie 1:859-864.

Dumas de Vaulx, R., D. Chambonnet, and M. Sibi 1982. Stimulation of in vitro androgenesis in pepper (Capsicum annuum) by elevated temperature treatments, p. 92-98. In: E. Earle and Y. Demarly (eds.). Variability in plants regenerated from tissue culture. Praeger Publication, New York, NY

El-Hennawy, M.A., A.F. Abdalla, S.A. Shafey, and I.M. Al-Ashkar. 2011. Production of doubled haploid wheat lines (Triticum aestivum L.) using anther culture technique. Ann. Agr. Sci. 56:63-72.

Ercan, N., F.A. Sensoy, and A.S. Sensoy. 2006 Influence of growing season and donor plant age on anther culture response of some pepper cultivars (Capsicum annuum L.). Sci. Hort. 110:16-20.

FAOSTAT. 2013. Food and Agriculture Organization of The United Nations. 23 Oct. 2014. <http:// faostat.fao.org/site/567/default.aspx\#ancor>.

Gémesné Juhász, A., M. Petus, G. Venczel, L. Zatykó, G. Gyulai, and M. Cséplö. 2001. Genetic variability of anther donor versus spontaneous doubled haploid descendents and colchicine induced doubled haploid sweet pepper (Capsicum annuum L.) lines. Acta Hort. 560:149-152.

George, L. and S. Narayanaswamy. 1973. Haploid Capsicum through experimental androgenesis. Protoplasma 78:467-470.

Gu, H.H., W.J. Zhou, and P. Hagberg. 2003. High frequency spontaneous production of doubled haploid plants in microspore cultures of Brassica rapa ssp. chinensis. Euphytica 134:239-245.

Gulsen, O., S.S. Mutlu, N. Mutlu, M. Tuna, O. Karaguzel, R.C. Shearman, T.P. Riordan, and T.M. Heng-Moss. 2009. Polyploidy creates higher diversity among Cynodon accessions as assessed by molecular markers. Theor. Appl. Genet. 118:1309-1329.

Harn, C., M.Z. Kim, K.T. Choi, and Y.I. Lee. 1975. Production of haploid callus and embryoid from the cultured anther of Capsicum annuum. Sabrao J. 7:71-77.

Hoekstra, S., M.H. Van Zijderveld, F. Heidekamp, and F. Van der Mark. 1993. Microspore culture of Hordeum vulgare L.: The influence of density and osmolarity. Plant Cell Rpt. 12:661-665.

IBPGR. 1983. Genetic resources of Capsicum. IBPGR Secretariat, Rome, 49.

Irikova, T., S. Grozeva, and V. Rodeva. 2011. Anther culture in pepper (Capsicum annuum L.) in vitro. Acta Physiol. Plant, doi: 10.1007/ s11738-011-0736-6.

Kahrizi, D. and R. Mohammadi. 2009. Study of androgenesis and spontaneous chromosome doubling in barley (Hordeum vulgare L.) genotypes using isolated microspore culture. Acta Agronomica Hungarica 57:155-164. 
Kim, K.M. and P.S. Baenziger. 2005. A simple wheat haploid and doubled haploid production system using anther culture. In Vitro Cell Dev. Biol. Plant 41:22-27.

Kim, Y.S., Y.I. Kuk, and K.M. Kim. 2007. Inheritance and expression of transgenes through anther culture of transgenic hot pepper. Z. Naturforsch. C 62:743-746.

Koleva-Gudeva, L., F. Trajkova, G. Dimeska, and M. Spasenoski. 2009. Androgenesis efficiency in anther culture of pepper (Capsicum annuum L.). Acta Hort. 830:183-190.

Loureiro, J., E. Rodriguez, J. Dolezel, and C. Santos. 2006. Comparison of four nuclear isolation buffers for plant DNA flow cytometry. Annals of Botany 98:679-689.

Mirzaei, M., D. Kahrizi, and A. Rezaeizad. 2011a. Androgenesis and spontaneous chromosome doubling in Triticum aestivum L. Researches of the First International Conference. Babylon and Razı Universities.

Mirzaei, M., D. Kahrizi, and A. Rezaeizad. 2011b. Androgenesis and spontaneous chromosome doubling in Hordeum vulgare L. Researches of the First International Conference. Babylon and Razı Universities.

Mohammadi, P.P., A. Moieni, and M. JalaliJavaran. 2007. Colchicine induced embryogenesis and doubled haploid production in maize (Zea mays L.) anther culture. Iranian J. Biotechnol. 5:140-146.

Morrison, R.A., E.R. Koning, and D.A. Evans, 1986. Anther culture of an interspecific hybrid of Capsicum. J. Plant Physiol. 126:1-9.

Murashige, T. and F. Skoog. 1962. A revised medium for rapid growth and bio assay with tobacco tissue cultures. Physiol. Plant. 15:473-497.
Niklas-Nowak, A., D. Olszewska, A. Kisiala, and P. Nowaczyk. 2012. Study of individual plant responsiveness in anther cultures of selected pepper (Capsicum spp.) genotypes. Folia Hort. 24:141-146.

Novak, F.J. 1974. Induction of a haploid callus in anther cultures of Capsicum sp. Z. Pflanzenphysiol. 68:97-114.

Olszewska, D., A. Kisiala, A. Niklas-Nowak, and P. Nowaczyk. 2013. Study of in vitro anther culture in selected genotypes of genus Capsicum. Turk. J. Biol. 38:118-124.

Ozkan, H., M. Tuna, and D.W. Galbraith. 2006. No DNA loss in autotetraploids of Arabidopsis thaliana. Plant Breeding 125:288-291.

Ozkan, H., M. Tuna, B. Kilian, N. Mori, and S. Ohta. 2010. Genome size variation in diploid and tetraploid wild wheats. AoB Plants, doi: 10.1093/ aobpla/plq015.

Özkum Çiner, D. and R. Tipırdamaz. 2002. The effects of cold treatment and charcoal on the in vitro androgenesis of pepper (Capsicum annuum L.). Turk. J. Bot. 26:131-139.

Saccardo, F. and M. Devreux. 1974. In vitro production of plantlets from anther culture of Capsicum annuum L., p. 45-49. In: Proc. Eucarpia: Genet. Breeding of Capsicum.

Sibi, M., R. Dumas de Vaulx, and D. Chambonnet. 1980. Androgenese in vitro chez le Piment Capsicum annuum L.: Impact des pretraitements sur le taux de plantes regenerees, $\mathrm{p}$. 143-149. In: C.R. Reunion (ed.). EUCARPIA application de la culture in vitro a l'Amelioration des. Plantes Potageres, Versailles.

Stober, A. and D. Hess. 1997. Spike pretreatment, anther culture conditions, and anther culture response of 17 German varieties of spring wheat (Triticum aestivum L.). Plant Breeding 116:443-447.

Suda, J. and P. Travnicek. 2006. Reliable DNA ploidy determination in dehydrated tissues of vascular plants by DAPI flow cytometry-new prospects for plant research. Cytometry A. 69:273-280.

Taşkin, H., S. Büyükalaca, D. Keleş, and E. Ekbiç. 2011. Induction of microspore-derived embryos by anther culture in selected pepper genotypes. Afr. J. Biotechnol. 10:17116-17121.

Tiryaki, I. and M. Tuna. 2012. Determination of intraspecific nuclear DNA content variation in common vetch (Vicia sativa L.) lines and cultivars based on two distinct internal reference satndards. Turk. J. Agr. For. 36:645-653.

Tuna, M., D.K. Khandka, M.K. Shresta, K. Arumuganathan, and A. Golan-Goldhirsh. 2004. Characterization of Dactylis polpulations collected from natural ranges of thrace region of Turkey based on ploidy and RAPD analysis. Euphytica 135:39-46.

Tuna, M., K.P. Vogel, and A. Arumuganathan. 2006. Cytogenetic and nuclear DNA content characterization of diploid Bromus erectus and Bromus variegatus. Crop Sci. 46:637-641.

Tuna, M., K.P. Vogel, K. Arumunagathan, and K.S. Gill. 2001. DNA contents and ploidy determination of bromegrass germplasm accessions by flow cytometer. Crop Sci. 41:1629-1634.

Vanous, A.E. 2011. Optimization of doubled haploid production in maize (Zea mays L.). Iowa State Univ., Iowa, MSc Diss.

Wang, Y.Y., C.S. Sun, C.C. Wang, and N.J. Chien. 1973. The induction of polen plantlets of Triticale and Capsicum annuum from anther culture. Sci. Sin. 16:147-151. 